\title{
EL MUNICIPIO Y LA PROVINCIA EN LA CONSTITUCIÓN DE 1812
}

\author{
JAVIER GARCÍA FERNÁNDEZ
}


SUMARIO

1. INTRODUCCIÓN. 2. LOS ANTECEDENTES NORMATIVOS Y EL DEBATE CONSTITUCIONAL. 3. REGULACIÓN CONSTITUCIONAL. 4. CARACTERÍSTICAS DEL RÉGIMEN LOCAL EN LA CONSTITUCIÓN. 5. EL PROFUSO DESARROLLO NORMATIVO DE 1812-1813. I. DISPOSICIONES ANTERIORES A LA INSTRUCCIÓN PARA EL GOBIERNO ECONÓMICO-POLÍTICO DE LAS PROVINCIAS. 6. EL PROFUSO DESARROLLO NORMATIVO DE 1812-1813. II. LA INSTRUCCIÓN PARA EL GOBIERNO ECONÓMICO-POLÍTICO DE LAS PROVINCIAS DISPOSICIONES CONCORDANTES. 7. CONCLUSIÓN. 


\title{
EL MUNICIPIO Y LA PROVINCIA EN LA CONSTITUCIÓN DE 1812
}

POR

\author{
JAVIER GARCÍA FERNÁNDEZ \\ Catedrático de Derecho constitucional \\ Universidad Complutense de Madrid
}

\section{INTRODUCCIÓN}

En el marco de la reforma jurídica que aprueban las Cortes de Cádiz, el régimen local se perfila con rasgos peculiares y de gran relevancia. Esta peculiaridad y esta relevancia se explican por las siguientes circunstancias:

a) afectaba a la «infraestructura» de la sociedad, de la misma manera que la creación de las Cortes y la regulación del Poder Ejecutivo dual afectaban a la «superestructura» del Estado: si al acabar la Guerra se hubieran podido aplicar las reformas gaditanas del régimen local, la estructura social de España se hubiera transformado radicalmente. Lo que ahora llamaríamos «tejido social» de la España de principios del siglo XIX se estructuraba en torno al pueblo o la villa por lo que el modo de gobernar estos pueblos o estas villas tenía incidencia inmediata sobre los habitantes de estos lugares;

b) conectaba con la posición de la nobleza y de la Iglesia, las cuales habrían perdido poder institucional al suprimirse los señoríos jurisdiccionales: el poder local habría pasado de las oligarquías aristocráticas y eclesiásticas a los habitantes varones de las ciudades, villas y lugares convertidos en ciudadanos; y 
c) venía a fortalecer extraordinariamente el Poder Ejecutivo al convertir a las Ayuntamientos y a las Diputaciones Provinciales en un elemento constitutivo de la organización periférica de este Poder. La organización local se insertaba pues en el principio de separación de poderes tanto en un sentido dogmático ${ }^{1}$ como práctico pues la anterior estructura señorial había imposibilitado que el Monarca poseyera una red periférica que alcanzara todo el territorio. Ni siquiera con el cambio centralizador implantado por los Borbones el Rey desplegaba su poder hasta el último lugar de España.

Por eso el régimen local que dimana de la Constitución de 1812 y de la normativa pre y pos constitucional elaborada por las Cortes tiene una especial importancia en la historia constitucional española. Sin duda, una trascendencia muy superior a la que tuvieron los artículos de contenido local del Título I de la Constitución de 1931 o el Capítulo Segundo del Título VIII de la Constitución de 1978. Ello es así porque por muy innovadores que fueran los artículos 9 y 10 de la Constitución de 1931 o los artículos 140 a 142 de la Constitución de 1978 (que no lo eran ni lo son), venían a regular una estructura jurídica asentada desde hacía muchas décadas, con sus principios dogmáticos y su estructura orgánica bien establecidos, en tanto que las previsiones de la Constitución gaditana y normativa concordante venían a crear unas instituciones político-administrativas nuevas con inmediata incidencia en las relaciones de poder local de toda la nación ${ }^{2}$.

Vamos a examinar, en primer lugar, las previsiones constitucionales que sobre el régimen local contenía la Constitución. En segundo lugar, aportaremos una reflexión sobre el alcance y la génesis de esta regulación. Y en tercer lugar, examinaremos la normativa que las propias Cortes produjeron en desarrollo de la Constitución.

${ }^{1}$ El principio de separación de poderes aparece en el Derecho histórico cuando las Cortes de Cádiz aprueban su Decreto I, de 24 de septiembre de 1810, que declara legítima la constitución de éstas y su soberanía y afirma: «No conviniendo queden reunidos el Poder legislativo, el ejecutivo y el judiciario...» (Colección de los Decretos y Ordenes que han expedido las Cortes Generales y Extraordinarias desde su instalacion en 24 de Septiembre de 1810 hasta igual fecha de 1811. Mandada publicar en orden de las mismas, Imprenta Real, Cádiz, 1811, págs. 1-3).

${ }^{2}$ Sobre los modelos de organización municipal que se ponen en marcha en Cádiz, Javier GARCíA FERNÁNDEZ. «El municipio en los orígenes del constitucionalismo español. Notas sobre la génesis de la organización municipal a través de tres modelos constitucionales», en El municipio constitucional. II Seminario de Historia de la Administración, Instituto Nacional de Administración Pública, Madrid, 2003, págs. 47-55. 


\section{LOS ANTECEDENTES NORMATIVOS Y EL DEBATE CONSTITUCIONAL}

A causa de esa trascendencia intensa e inmediata del régimen local configurado en la Constitución, llama mucho la atención que en las Cortes el debate sobre el gobierno local no tuviera excesiva trascendencia ${ }^{3}$.

Para la importancia del tema, escasa importancia tuvo la organización municipal en las respuestas que instituciones y particulares remitieron en contestación a la «Consulta al País» que la Junta Central formuló en el Decreto de 22 de mayo de 1809 simultáneamente a la convocatoria de Cortes, si bien hay que decir que las preguntas formuladas por la Junta Central no aludían directamente a temas municipales ${ }^{4}$. No obstante, de las reflexiones y opiniones más o menos colaterales se deducía que nadie sentía nostalgia por un modelo municipal caducado, que nadie se paraba a valorar el complejo gubernativo-judicial que caracterizaba a los cargos municipales y que, en todo caso, si había alguna preocupación en el ámbito local eran las que dimanaban de la venta de oficios y de los señoríos jurisdiccionales. En todo caso, en las respuestas a la Consulta no encontramos elementos que prefiguren el amplio tratamiento que tres años después encontraremos en el Título VI de la Constitución y en la Instrucción de $1813^{5}$.

3 Véase GARCÍA FERNÁNDEZ: El origen del municipio constitucional: autonomía y centralización en Francia y en España, Instituto de Estudios de Administración Local, Madrid, 1983, págs. 211-273, donde ha tratado con detalle las diversas fases del debate municipal en las Cortes.

${ }^{4}$ No hay, como se sabe, una publicación que recoja todas las respuestas. Las publicó muy parcialmente Manuel Fernández Martín: Derecho Parlamentario Español. Colección de Constituciones, disposiciones de carácter constitucional, leyes y decretos electorales para diputados y senadores, y reglamentos de las Cortes que han regido en España en el presente siglo, Imp. de los Hijos de J. A. García, Madrid, 1885. Extractó algunas respuestas Fernando JiméneZ de GRegorio: La Convocación de Cortes Constituyentes en 1810. Estado de la opinión española en punto a la reforma constitucional, Plasencia, 1936 (reproducido en Estudios de Historia Moderna, Consejo Superior de Investigaciones Científicas, Barcelona, 1955, págs. 223-347). Una parte importante las respuestas ocupaban el segundo tomo de Miguel ARtola: Los orígenes de la España contemporánea, Instituto de Estudios Políticos, Madrid, 1975, $2^{\mathrm{a}}$ ed. Finalmente, el Seminario de Historia Moderna de la Universidad de Navarra publicó una parte importante de los Informes Oficiales sobre Cortes, Universidad de Navarra, Pamplona, 1967 (Baleares), 1968 (Valencia y Aragón) y 1974 (Andalucía y Extremadura), con «Estudio Preliminar» de Federico SuÁrez Verdaguer (págs. 11-104 del tomo dedicado a Baleares). Al lado de esta documentación debe, citarse el estudio de María Isabel ArRIAZu «La Consulta de la Junta central al País sobre Cortes», en la obra col. Estudios sobre Cortes de Cádiz, Universidad de Navarra, Pamplona, 1967, págs. 15-117.

5 Sobre el contenido municipal de las respuestas a la Consulta, GARCí́ FERNÁNDEZ: El origen del municipio constitucional: autonomía y centralización en Francia y en España, cit., págs. 216-231; Enrique ORduña Rebollo: Municipios y Provincias. Historia de la Organización Territorial Española, Federación Española de Municipios y Provincias — Instituto Nacional de Administración Pública— 
Pero si las entidades y particulares consultados afinaron poco en las propuestas, las propias Cortes, antes de aprobar la Constitución, avanzaron con disposiciones de cierta importancia que fueron fijando ciertos hitos para una regulación tan detallada como la que introdujo la propia Constitución. Estas disposiciones preconstitucionales estaban motivadas por dos razones, coyuntural una, política revolucionaria la otra. Por una parte, las exigencias de la guerra, la urgencia de articular la autoridad civil con la autoridad militar para hacer más eficaces los Ejércitos que combatían al invasor, obligaron a dictar algunas normas sobre la organización administrativa territorial, organización subordinada a los mandos militares. Por otro lado, en las Cortes predominaba el espíritu revolucionario y ese espíritu inducía a cambios políticos y socio-económicos que habían de tener proyección sobre la Administración territorial. Eso explica que tras su constitución las Cortes aprobaran varios Decretos que muestran una cierta concepción de la futura Administración Local.

Como ha recordado Fernández Sarasola, apenas unas semanas después de constituirse las Cortes se creó una Comisión encargada de elaborar un proyecto de reglamento sobre el arreglo de las Provincias y es en esta Comisión donde se dieron los primeros enfrentamientos entre centralistas y descentralizadores. El proyecto se elaboró pero fue rechazado a finales de diciembre de $1810^{6}$ pero con una dimensión mucho más centrada en la organización militar, las Cortes aprobaron otro que prefiguraba la futura organización provincial: el Decreto XXV, de 25 de enero de 1811, que establecía «Providencias que deben tomar las Juntas provinciales en caso de invasion de los enemigos» ${ }^{7}$. En este Decreto, las atribuciones extraordinarias y provisionales de las Juntas Provinciales apuntaban ya a un conjunto de potestades permanentes y definitivas (tributarias, abastecimientos, etc.) que posteriormente asumiría el Poder Ejecutivo por medio de las Diputaciones Provinciales.

Como el Decreto XXV era una disposición de urgencia, las Cortes pretendieron establecer una regulación más amplia (aun en el marco de la organización militar) y así dictaron el Reglamento provisional para el gobierno de las Juntas de provincia, aprobado por Decreto XLIII, de 18 de marzo de $1811^{8}$. Era tam-

Centro de Estudios Políticos y Constitucionales, Madrid, 2003, págs. 276-283; Orduña ReBolLo: Historia del Municipalismo Español, Iustel, Madrid, 2005, págs. 125-131.

${ }^{6}$ Ignacio Fernández Sarasola: La Constitución de Cádiz. Origen, contenido y proyección constitucional, Centro de Estudios Políticos y Constitucionales, Madrid, 2011, págs. 214-216.

7 Colección de los Decretos y Ordenes..., cit., t. I, págs. 59-61.

${ }^{8}$ Colección de los Decretos y Ordenes..., cit., t. I, págs. 90-103. Hay un breve comentario a este Decreto en Fernández SARASOla: La Constitución de Cádiz. Origen, contenido y proyección constitucional, cit., págs. 216-217. 
bién un Reglamento provisional por su carácter preconstitucional y orientado a las necesidades de la Defensa pero no por su concepción pues configuraba un régimen provincial nítido para asentar la nueva estructura territorial del Estado y por eso muchos de sus contenidos emergerán en la Constitución o en la Instrucción de 1813. De esta manera, se estableció un órgano provincial (la Junta Superior) elegido con las mismas reglas que para las elecciones a Diputados de Cortes, exigiéndose a los elegidos bienes o arraigo en la Provincia, sirviendo gratuitamente sus cargos. Su composición era de nueve miembros salvo en las Provincias donde hubiera más Corregimientos o Partidos que tendrían tantos miembros como unidades en que ésta esté dividida. El Intendente (que subsistía) era miembro nato de la Junta y siempre estaba presidida por el Capitán General (previsión comprensible en la situación en que se vivía) pero con un Vicepresidente elegido entre sus miembros por éstos. El mandato era de tres años y se renovaba por tercios. También estaban dotadas de un Secretario elegido por el propio órgano.

Las naturaleza de las Juntas como órgano de coordinación entre el Poder Ejecutivo y los «pueblos» se definía bien en su artículo XIII: «Las Juntas han de ser conducto por donde el Gobierno comunique a los pueblos las órdenes gubernativas» y además se le atribuía funciones recaudatorias, educativas ${ }^{9}$, deportivas (que la juventud se habilite en ejercicios gimnásticos y manejo de armas), de creación de establecimientos administrativos, y sanitarias (creación de hospitales). El carácter periférico de las Juntas se acentuaba al ordenar el Decreto que se crearan Comisiones de las mismas en cada cabeza de Partido o Corregimiento y Comisiones en cada pueblo de más de doscientos vecinos, encargadas de ejecutar las providencias de las Juntas provinciales.

A pesar de su insuficiente regulación no dejaba de tener importancia de cara a la futura ordenación municipal el artículo XLVI que contenía criterios de delimitación entre las Juntas y los Tribunales ${ }^{10}$.

Aunque las Juntas se insertaban en un marco bélico como decía su artículo $\mathrm{XXVI}^{11}$, y muchos de sus preceptos eran disposiciones de carácter militar ${ }^{12}$, es

9 «Emplearán particularmente su zelo en fomentar y establecer escuelas de primeras letras para ambos sexôs», ordenaba su artículo XXII.

10 Juan Alfonso Santamaría PAStor: Sobre la génesis del Derecho administrativo español en el siglo XIX (1812-1854), Instituto García Oviedo, Sevilla, 1973 (hay ed. posterior), pág. 56.

11 «Como las Juntas de provincia se han constituido para auxiliar á los xefes militares, y proporcionar los medios de defensa y los suministros a la tropa...».

12 Poco después las Cortes dictaron el Decreto LXXVIII, de 21 de julio de 1811, por el que «Se obliga á las Juntas provinciales á prestar los socorros que pidan los Generales: se autoriza á estos para compelerlas en el único caso de morosidad» (Colección de los Decretos y Ordenes..., cit., t. I, 
evidente que prefiguraban, ensayando, un modelo de estructura territorial que luego se fijó en la Constitución.

Ya sin alcance ni finalidad militar y sí con el fin de transformar la estructura social y municipal del país se dicta el Decreto LXXXII, de 6 de agosto de 1811, de «Incorporacion de los señoríos jurisdiccionales á la Nacion: los territoriales quedarán como propiedades particulares: abolición de los privilegios exclusivos, privativos y prohibitivos: modo de reintegrar á los que obtengan estas prerrogativas por título oneroso, ó por recompensa de grandes servicios: nadie puede llamarse Señor de vasallos, ni ejercer jurisdicción §» (que así se intitulaba $)^{13}$. El Decreto, como es sabido, es la norma que deroga el régimen feudal en España pero como el feudalismo tenía base territorial sus efectos se desplegaban en el ámbito de las instituciones municipales. Sin entrar en el grueso de los temas socio-económicos (por otra parte, bastante moderado pues no puso en cuestión la propiedad de la tierra), desde un punto de vista municipal el Decreto LXXXII confiere naturaleza jurídico-pública a los cargos concejiles que rigen los «pueblos» uniformando todos los Municipios mediante la prohibición de nombrar Jueces y ejercer jurisdicción, lo que comportaba la supresión de la distinción lugar de realengo/ lugar de señorío. También tuvo incidencia sobre las competencias municipales por cuanto los llamados derechos feudales, los llamados derechos exclusivos que comprendían la caza, la pesca, los hornos, los molinos, los aprovechamientos de agua, montes y demás actividades, se liberaron con arreglo al Derecho común y su regulación singular se deferió a las reglas municipales ${ }^{14}$. En una sociedad predominantemente agraria la inclusión de los derechos feuda-

págs. 179-180). Como la ejecución de este Decreto debió provocar ciertas tensiones entre las autoridades civiles y militares, las Cortes, tras recibir una exposición de la Junta Provincial de Galicia, dictaron la Orden de 9 de enero de 1812 «Por la qual se manda reencargar á los generales de los exércitos la consideracion que deben tener con las Juntas provinciales en el cumplimiento del decreto de 21 de Julio último» (Colección de los Decretos y Ordenes que han expedido las Cortes Generales y Extraordinarias desde 24 de Setiembre de 1811 hasta 24 de Mayo de 1812. Mandada publicar de orden de las mismas, cit., t. II, 1813, págs. 49-50.

13 Colección de los Decretos y Ordenes..., cit., t. I, págs. 193-196.

${ }^{14}$ Sobre este Decreto y sus antecedentes, Rafael García Ormaechea: Supervivencias Feudales en España. Estudio de legislación y jurisprudencia sobre señoríos, Reus, Madrid, 1932; Salvador de Moxó: Incorporación de señoríos a la Corona, Facultad de Filosofía y Letras de la Universidad de Valladolid, Consejo Superior de Investigaciones Científicas, Valladolid, 1959; GARCíA FernÁNDEZ: El origen del municipio constitucional: autonomía y centralización en Francia y en España, cit., págs. 234243. Más reciente, Orduña Rebollo: Municipios y Provincias. Historia de la organización Territorial Española, cit., págs. 285-287; Eduardo GALVÁN RODRíGUEZ: «La disolución del régimen señorial», en José Antonio Escudero (dir.): Cortes y Constitución de Cádiz. 200 años, Espasa, Madrid, 2011, t. II, págs. 204-219; Jaime de SALAZAR Y ACHA: «La supresión de los privilegios nobiliarios», en Es- 
les de muchos lugares en el Derecho común transformaba las bases económicas del Municipio y fortalecía el nuevo Ayuntamiento. En todo caso, el hecho tuvo tanta trascendencia para la organización municipal que el propio Jovellanos, que pedía que se indemnizara a los propietarios de estos oficios, consideró que mientras estuvieran enajenados los oficios municipales los Ayuntamientos de ciudades y villas no serían representativos ${ }^{15}$.

La abolición de los señoríos no prejuzgaba, empero, el modelo de organización municipal que las Cortes establecerían. Lo prueba la contraposición de los artículos II y III del Decreto pues mientras que el primero de estos preceptos ordenaba nombrar «Justicias y demas funcionarios públicos», el artículo III, con alguna mayor precisión, ordenaba el cese de «Corregidores, Alcaldes mayores y demas empleados públicos». Se sabía los cargos que se quería abolir pero aún no se conocían cuáles se crearían. Lo corrobora la Orden de las Cortes de 9 de noviembre de 1811 por la que «Se prohibe por ahora la provision de los Corregimientos y Alcaldías mayores de los lugares que fueron de Señorio» ${ }^{16,17}$.

Como se ve, los Diputados no eran ajenos a los problemas del régimen local y a las posibles vías de reforma que la Guerra auspiciaba. Sin embargo, en el debate constitucional propiamente dicho los temas municipales no emergieron con fuerza ni con profundidad.

Entre el 27 de septiembre y el 18 de noviembre de 1811 la Comisión de Constitución ${ }^{18}$ debatió los temas municipales y provinciales que luego consti-

CUDERo (dir.): Cortes y Constitución de Cádiz. 200 años, cit., t. II, págs. 309-320; y A. Carlos MerCHÁN FERNÁNDEZ: «Notas sobre el gobierno municipal ante la planta constitucional de 1812», en EsCudero (dir.): Cortes y Constitución de Cádiz. 200 años, cit., t. III, págs. 276-282.

15 Gaspar Melchor de Jovellanos: «Consulta de convocación de las Córtes por estamentos» (21 de mayo de 1809), reproducido en Fernández Martín: Derecho Parlamentario Español..., cit., t. I, pág. 470-471.

${ }_{16}$ Colección de los Decretos y Ordenes que han expedido las Cortes Generales y Extraordinarias desde 24 de Septiembre de 1811 hasta 24 de Mayo de 1812, cit., t. II, pág. 28.

17 Un tema interesante para los historiadores es el estudio empírico de los procesos de cese de Corregidores y Alcaldes Mayores en los lugares de señorío, si se produjeron o no, y qué cargos se crearon para sustituirlos.

18 Estos debates los ha publicado el Seminario de Historia Moderna de la Universidad De Navarra: Actas de la Comisión de Constitución (1811-1813), Instituto de Estudios Políticos, Madrid, 1976, coordinadas por Federico SuÁreZ y «Estudio preliminar» de María Cristina DízLOIS. Acerca de la Comisión de Constitución, además del trabajo de DIZ-LOIS, véase FernánDEZ Martín: Derecho Parlamentario Español..., cit., t. II, pág. 287-327, y, más reciente ORdUÑa ReBOLLO: Municipios y Provincias. Historia de la organización Territorial Española, cit., págs. 287-291; Miguel Artola y Rafael Flaquer MonTeQui: La Constitución de 1812, Iustel, Madrid, 2008, págs. 49-63; y Fernández Sarasola: La Constitución de Cádiz. Origen, contenido y proyección constitucional, cit., págs. 69-87. 
tuirían el Título VI de la Constitución. En los debates de esos dos meses se asentó la disociación, personificada en el Alcalde, entre lo gubernativo y lo contencioso, prefigurada, como hemos visto, en el Decreto XLIII, pero que en la Comisión dio lugar a enfrentamientos que sabemos aparecieron aunque sin conocerse su alcance. También se sabe que los Diputados americanos no aceptaban la propuesta que se debatía, quizá porque deseaban acentuar el modelo uniformista. Pero una vez admitidos los puntos nucleares (implantación general de los Ayuntamientos, remisión a la Ley para fijar su composición, elección de Alcaldes, Regidores y Procuradores Síndicos, cese de los Regidores Perpetuos) los restantes temas centrales del nuevo régimen municipal emergieron en la Comisión sin apenas debate (sistema electoral, competencias, cierta potestad tributaria, tutela ejercitada por las Diputaciones Provinciales $)^{19}$. En todo caso, de las actas de la Comisión no es posible deducir si el modelo municipal surgió de una meditación autóctona (o americana, dada la actitud activa de los Diputados americanos en todo este Título VI) o por influencia francesa ni tampoco podemos saber la posición y el pensamiento de los Diputados conservadores que no debían estar satisfechos con la supresión de la parte jurisdiccional de los señoríos.

Más discusión hubo en el Pleno de la Cámara ${ }^{20}$. Por de pronto, los Diputados peninsulares se mostraban muy reticentes a la noción de autonomía municipal por temor al federalismo que ya emergía en el continente americano. Pero superada esta cuestión el Pleno entró en el gran debate de la naturaleza de los Ayuntamientos, donde el Conde de Toreno presentó su conocida definición: «Los Ayuntamientos no son más que unos agentes del poder ejecutivo para el gobierno económico de los pueblos; pero... se prefirió que estos agentes sean escogidos por sus propios vecinos...» ${ }^{21}$. También en los debates plenarios apareció la espe-

19 GARCía FernÁNDEZ: El origen del municipio constitucional: autonomía y centralización en Francia y en España, cit., págs. 243-256.

20 Además del Diario de las discusiones y actas de las Cortes, los debates están recogidos en Enrique Orduña Rebollo y Luis Cosculluela Montaner: Historia de la legislación de régimen local (Siglos XVIII a XX), Iustel, Fundación Democracia y Gobierno Local, Madrid, 2088, págs. 253295. Sobre estos debates GARCÍA FERNÁNDEZ: El origen del municipio constitucional: autonomía y centralización en Francia y en España, cit., págs. 256-273; ORduña ReBOLlo: Historia del Municipalismo Español, cit., págs. 131-138; Ángeles Hijano Pérez: «El Ayuntamiento liberal», en El municipio constitucional. II Seminario de Historia de la Administración, cit., págs. 269-285; ARTOLA y Flaquer Montequi: La Constitución de 1812, cit., págs. 63-69.

21 Diario de las discusiones y actas de las Cortes, Imprenta Real, Cádiz, 1812, t. 11, sesión del 10 de enero, pág. 210. Véase Joaquín VARELA SuANZES-CARPEGNA: «Nación, representación y articulación territorial del Estado en las Cortes de Cádiz», en IDEM: Política y Constitución en España (1808-1978), Centro de Estudios Políticos y Constitucionales, Madrid, 2007, págs. 218-223. An- 
rable oposición a la supresión de los oficios perpetuos que permitió a Toreno, frente al activo clérigo conservador guatemalteco Antonio de Larrazábal y Arrivillaga, fijar con nitidez las diferencias entre lo gubernativo y lo contencioso mientras que el alambicado sistema de sufragio indirecto pasó sin mayores discusiones $^{22}$. También pasó sin apenas discusión la naturaleza jurídica y política del Alcalde, órgano que sólo atraía los debates cuando emergía su antigua naturaleza jurisdiccional. Ningún debate suscitó el novedoso sistema de fuentes del Derecho municipal y muy poco la larga relación de competencias municipales salvo en aquellas atribuciones que afectaban a la Iglesia católica (escuelas y hospitales) donde aparecieron ciertas reticencias eclesiásticas.

\section{REGULACIÓN CONSTITUCIONAL ${ }^{23}$}

Por su carácter ultra-innovador y porque la sociedad que se deseaba reformar por medio de la Constitución tenía una sólida estructura municipal, la Constitución de 1812 dedicó una parte importante de su contenido regulador al régimen local, contenido que no se circunscribía al Título dedicado a la Administración local.

De entrada, la Constitución tenía en su Título II (Capítulo I) un precepto que muy pocas veces se habría de repetir en el constitucionalismo histórico español: el artículo 10 que señalaba los territorios de que se componía España, tanto en la península como en Ultramar, artículo que se complementaba con el 11 que preveía una «división más conveniente del territorio» cuando las circunstancias lo permitieran y que se haría mediante «ley constitucional», lo que sacaba

teriormente, del mismo Varela Suanzes-Carpegna: El conde de Toreno. Biografía de un liberal (1786-1843), Marcial Pons, Madrid, págs. 73-95.

22 Donde hubo más debate fue en un tema que ya entonces empezaba a estar rebasado: el derecho electoral de las castas (los grupos mestizos americanos) que los Diputados americanos defendieron con gran intensidad.

${ }^{23}$ Para el contenido municipal y provincial de la Constitución, además de la bibliografía recogida en García FERNÁNDEZ: El origen del municipio constitucional: autonomía y centralización en Francia y en España, cit., véanse, como trabajos más recientes: F. CARANTOÑa ÁlVAREZ: «Liberalismo y administración territorial. Los poderes local y provincial en el Sistema Constitucional de Cádiz», en Alberto GIl Novales (ed.): La revolución Liberal, Eds. del Orto, Madrid, 2001, págs. 135-58; Jesús GONZÁLEZ SALINAS: «La organización local en el siglo XIX: su regulación según el modelo de la Constitución de Cádiz», en Nuevas perspectivas del régimen local: estudios en homenaje al profesor José María Boquera Oliver, Tirant lo Blanch, Valencia, 2002, págs. 544-576; ORduÑa REBOLlO: Municipios y Provincias. Historia de la organización Territorial Española, cit., págs. 295-302, y José CANO: «El gobierno de los pueblos», en EsCudero (dir.): Cortes y Constitución de Cádiz. 200 ã̃os, cit., t. II, págs. 283-294. 
el tema de la competencia del Parlamento para retornar al Poder Constituyente. Este artículo 11 utilizaba el sustantivo «división» a secas por lo que podía referirse a cualquier tipo de circunscripción territorial pero el artículo 326, que contenía una remisión a ese mismo artículo 11 , precisaba más y se refería a la «nueva división de provincias», con lo que el texto constitucional venía a consagrar a la Provincia como circunscripción territorial de España ${ }^{24}$.

En el Capítulo IV del mismo Título II, el artículo 23 establecía que sólo los ciudadanos podrían obtener empleos municipales y elegir para ellos. El término empleo se refiere aquí a los cargos electivos y provocó, como acabamos de señalar, debates de cierta importancia en las Cortes porque excluía a las «castas» (los mestizos) y a los indios ${ }^{25}$.

Antes de llegar al Título correspondiente al régimen local, la Constitución contenía otras varias previsiones de incidencia local, a saber:

- entre las atribuciones de las Cortes estaba el aprobar el repartimiento de las contribuciones entre las Provincias (artículo 131.15 );

- los Alcaldes de los pueblos tendrían facultades en lo contencioso y en lo económico (artículo 275).

- el Alcalde en cada pueblo ejercerá el oficio de conciliador en los negocios civiles o por injurias. En este caso, el Alcalde, con dos hombres buenos nombrados por las partes, pondrá fin al litigio «si las partes se aquietan con esta decision extrajudicial» (artículos 282-284).

Sobre esta doble dimensión de los Alcaldes volveremos más adelante.

Además de estas previsiones, el Título VI estaba dedicado al gobierno interior de las Provincias y de los Pueblos, donde el Capítulo I (artículos 309-323) regulaba los Ayuntamientos y el Capítulo II (artículos 324-337) se dedicaba al gobierno político de las Provincias y a las Diputaciones Provinciales ${ }^{26}$. Conforme

24 Sobre los artículos 10 y 11 de la Constitución, Rafael GARCía PÉREZ: «Los territorios de la Península, América, Asia y África», en José Antonio Escudero (dir.): Cortes y Constitución de Cádiz. 200 años, Espasa, Madrid, 2011, t. II, págs. 686-694.

25 GARCíA FERNÁNDEZ: El origen del municipio constitucional: autonomía y centralización en Francia y en España, cit., págs. 268-269. Sobre la inserción de mestizos e indios en la nueva organización política, Bartolomé Clavero: «Hemisferios de ciudadanía: Constitución española en la América indígena», en José Álvarez JunCo y Javier Moreno Luzón (eds.): La Constitución de Cádiz: historiografúia y conmemoración. Homenaje a Francisco Tomás y Valiente, Centro de Estudios Políticos y Constitucionales, Madrid, 2006, págs. 101-142.

26 Para el debate parlamentario de este Título VI, GARCía FERNÁNDEZ: El origen del municipio constitucional: autonomía y centralización en Francia y en España, cit., págs. 254-273. También lo ha na- 
a este Título, el régimen local que establecía la Constitución se organizaba de acuerdo con los siguientes puntos:

a) Estructura territorial ${ }^{27}$. A pesar de la compleja composición territorial que recordaba (más que establecía) el artículo 10 que se extendía a lo largo de la Península, África, América y Asia, composición de naturaleza histórica, la Constitución, sin excepción de continentes, establecía una estructura territorial uniformista: España se dividía en Provincias y las Provincias en Municipios. La Constitución venía a fijar los órganos políticos que correspondían a estos niveles territoriales. El criterio delimitador de estos niveles era para el Municipio, en último término, el de la población: «no pudiendo dejar de haberle [el Ayuntamiento] en los [pueblos] que por sí o con su comarca lleguen a mil almas» (artículo 310). En cambio, para la Provincia no encontramos en toda la Constitución un criterio delimitador: habría Provincia cuando así lo estableciera la Ley constitucional a la que se refería el artículo $11^{28}$.

b) Organización municipal. En el ámbito territorial inferior, el Municipio era gobernado por el Ayuntamiento. El Ayuntamiento estaba formado por el o los Alcaldes, los Regidores y el Procurador Síndico (artículo 309). La determinación del número de estos empleos se defería a la Ley en proporción al vecindario (artículo 311). En todo Ayuntamiento habría también un Secretario elegido por el pleno y remunerado con fondos del común (artículo 320) y un Depositario (artículo $321.3^{\circ}$ ).

c) Régimen electoral del Ayuntamiento. El sistema electoral de los cargos municipales era tan alambicado como el de las Cortes. El principio era la elección y así el artículo 312 contenía un inciso final transitorio que ordenaba el cese de todos los oficios perpetuos. Igual que en la elección de los Diputados a Cortes, el procedimiento electoral estaba bastante detallado en los artículos 313 a 318 y consistía en lo siguiente: en el mes de diciembre de cada año se reunirían todos los vecinos para elegir electores (necesariamente residentes en el pueblo y en el goce de sus derechos de ciudadano). Estos electores elegirían todos los cargos del Ayuntamiento para que entraran a ejercitar sus funciones con el nuevo año. Los Alcaldes se elegirían todos los años, los Regidores cada dos años (la mitad cada año) al igual que los Procuradores Síndicos si hubiera dos (también la mitad cada

rrado recientemente Fernández Sarasola: La Constitución de Cádiz. Origen, contenido y proyección constitucional, cit., págs. 221-226.

27 Tomás-Ramón FernanÁDEZ: «El gobierno interior de las provincias y de los pueblos», en Escudero (dir.): Cortes y Constitución de Cádiz. 200 años, cit., t. III, págs. 232-242;

28 Sobre el debate enfrentado de los artículos 10 y 11, FernÁNDEZ SARASOla: La Constitución de Cádiz. Origen, contenido y proyección constitucional, cit., págs. 217-221. 
año). Si hubiera un solo Procurador Síndico se elegiría cada año. Los cargos concejiles eran obligatorios pero no podían elegirse como Alcaldes o Procuradores Síndicos los empleados al servicio del Rey.

Al igual que ocurría con las elecciones a Cortes, el sistema electoral de dos grados es uno de las cuestiones más discutibles en la Constitución, pues el doble grado ya suponía por sí mismo un filtro que aminoraba los beneficios del sufragio universal masculino que para el primer grado establecía el artículo 309. Tampoco resultaba práctica la renovación anual de los Alcaldes.

d) Atribuciones municipales. Los artículos 321 y 322 estaban dedicado a las competencias municipales, sin precisar si eran propias o delegadas por el Gobierno. Estas competencias se desglosaban en seis bloques: i) servicios públicos (policía de salubridad y comodidad, escuelas de primeras letras y otros establecimientos pagados con fondos del común, hospitales y demás establecimiento de beneficencia, construcción y reparación de vías de comunicación, de cárceles, de montes y plantíos y todas las obras públicas); ii) fomento (agricultura, comercio e industria); iii) auxilio al Alcalde en las atribuciones de éste (seguridad de las personas y bienes y conservación del orden público; iv) gestión económico-financiera (administración e inversión de caudales y reparto y recaudación de contribuciones); $v$ ) potestad tributaria, en los términos que veremos más abajo, y vi) potestad normativa por medio de Ordenanzas a las que luego nos referiremos. Sorprende en el artículo 321 la idea tan nítida de los servicios públicos municipales que Posada explicaba porque es en ese momento cuando aparecen las necesidades expansivas de la vida social lo que se traduce en servicios generales (higiene, educación, asistencia) ${ }^{29}$.

e) Régimen jurídico y procedimiento del Ayuntamiento. El artículo 321.8º, como acabamos de ver, configuraba la potestad normativa del Ayuntamiento mediante un procedimiento trifásico: el Ayuntamiento formaba las Ordenanzas, la Diputación Provincial las informaba y las Cortes las aprobaban. Como veremos más abajo, estamos ante una noción peculiar de las Ordenanzas: no son Reglamentos administrativos porque las aprueban las Cortes pero tampoco eran Leyes cuyo régimen estaba muy regulado en los Capítulos VIII y IX del Título III. Además, la intervención de la Diputación Provincial apuntaba a una cierta función tutelar de ésta, como veremos más abajo.

f) Naturaleza de la Diputación Provincial. Lo característico de las Diputaciones Provinciales es su carácter mixto, mitad representativo, mitad órgano diri-

29 Adolfo POSADA: Evolución legislativa del régimen local en España, 1812-1909, Librería general de V. Suárez, Madrid, 1910, págs. 3-5. 
gido directamente por el Poder Ejecutivo a través de su Jefe Superior que presidía este órgano (artículo 324). Es importante destacar que el gobierno político de la Provincia correspondía, no a la Diputación sino directamente al Jefe Superior en tanto que la Diputación tenía atribuida la función más indeterminada de promover la prosperidad de la Provincia como señalaba el artículo $325^{30}$.

g) Organización provincial. En la Diputación Provincial el uniformismo se acentúa aún más que en el Ayuntamiento. Toda Diputación estaba formada por el Presidente-Jefe Superior, el Intendente y siete «individuos» a los que la Constitución no daba especial denominación. Dado que, conforme al artículo 326 in fine, las Cortes podrían variar este número, debe pensarse que las Cortes gaditanas tenían una idea muy sumaria de la extensión o del número de habitantes que serían necesarios para establecer una Provincia. Como ocurría con el Ayuntamiento, también se elegía un Secretario dotado de los fondos públicos de la provincia» (artículo 333 in fine) y un Depositario (artículo 335.4\%).

h) Régimen electoral de las Diputaciones Provinciales. Los individuos que formaban la Diputación eran elegidos por los mismos electores de partido que elegían a los Diputados de las Cortes, es decir, conforme al Capítulo IV del Título III, eran elegidos por las Juntas de Partido que habían sido elegidas a su vez por las Juntas de Parroquia. Por ende, las Diputaciones Provinciales se formaban mediante una elección de segundo grado. Se renovaban por mitades cada dos años, sus miembros no eran inmediatamente reelegibles y se requería ser mayor de veinticinco años, en ejercicio de sus derechos y ser natural o vecino de la Provincia con siete años de residencia. También se requería «que tenga lo suficiente para mantenerse con decencia» (artículo 330) y no ser empleado del Rey.

i) Atribuciones provinciales. El artículo 335 establecía con detalle las atribuciones de las Diputaciones, que pueden glosarse de la siguiente manera: i) servicios públicos: promover la educación de la juventud, formar el censo y la estadística de la Provincia y cuidar de que los establecimientos piadosos y de beneficencia cumplan sus objetivos; ii) fomento de la agricultura, de la industria, del comercio y la protección de los inventores de nuevos descubrimientos; iii)) gestión y tutela económica y financiera: intervenir y aprobar el repartimiento de las contribuciones entre los pueblos, velar por la buena inversión de los fondos municipales, examinar las cuentas municipales para su elevación a la «aprobación superior» (artículo 335.2 ), proponer al Gobierno los arbitrios necesarios para obras nuevas o de reparación de las antiguas y dar parte al Gobierno de los abusos en la administración de las rentas públicas; iv) cuidar de que se esta-

30 Manuel SANTANA Molina: «El gobierno territorial: las Diputaciones provinciales», en EsCudero (dir.): Cortes y Constitución de Cádiz. 200 años, cit., t. III, págs. 243-256; 
blezcan Ayuntamientos donde corresponda; $v$ ) además, en las Provincias de Ultramar, velar por las «misiones para la conversión de los indios infieles» (artículo $335.10^{\circ}$ ). Llama la atención la distinta naturaleza de las atribuciones provinciales y municipales. Propias o delegadas, las competencias municipales eran de carácter sustantivo y estaban dirigidas a los servicios públicos las de las Diputaciones, aunque tiene alguna de esta naturaleza (la educación y la protección de los inventores) se dirige a otros dos ámbitos distintos como son la tutela financiera de los Ayuntamientos y el fomento, especialmente económico. Lo cual plantea otero tema: ¿el Jefe Superior era más «delegado de fomento» que «gobernador civil»?

j) Régimen jurídico y procedimiento de las Diputaciones Provinciales. A diferencia de los Ayuntamientos, a las Diputaciones se les ponía un límite de sesiones que consistía «en cada año a lo más noventa días de sesiones distribuidas en las épocas que más convenga» (artículo 334). Si pensamos en los días de sesiones que tiene actualmente cualquier Entidad Local, esta cifra denota una voluntad de trabajar muy notable. Además, encontramos las Cortes como tuteladoras de las Provincias: si el Rey suspende a los Vocales de las Diputaciones, hay que dar parte a las Cortes.

\section{CARACTERÍSTICAS DEL RÉGIMEN LOCAL EN LA CONSTITUCIÓN}

En las Cortes de Cádiz no se desconfiaba del Poder Ejecutivo. Lo demostraron muy tempranamente las propias Cortes cuando el Consejo de Regencia le dirigió una Memoria en donde solicitaba saber el alcance y límites del Poder Ejecutivo que ejercitaba en nombre del Rey prisionero de conformidad con el arriba, citado Decreto I, de 24 de septiembre, y el órgano parlamentario respondió por medio del Decreto IV, de 27 de septiembre de 1810: «en el decreto de 24 de Septiembre de este año no se han puesto límites a las facultades propias del Poder ejecutivo, y que ínterin se forma por las Córtes un reglamento que los señale, use [el Consejo de Regencia] todo el poder que sea necesario para la defensa, seguridad y administracion del estado en las críticas circunstancias del dia» ${ }^{31}$. Así se explica que el aparato administrativo más extenso de España, las Administraciones municipal y provincial, fueran convertidas por la Constitución en una rama del Poder Ejecutivo. Es cierto que una vez establecido el principio de separación de poderes, el diseño institucional no daba otro margen,

31 Colección de los Decretos y Ordenes..., cit., t. I, págs. 7-9 
como había ocurrido en Francia, pero en aquella época se conocía el ejemplo inglés.

No obstante, la Constitución optó claramente por una Administración local inserta en el Poder Ejecutivo que previamente había regulado por medio del Decreto XXIV, de 16 de enero de 1811, que aprobó el Reglamento provisional del Poder executivo ${ }^{32}$, cuyo Capítulo V ( «Del Consejo de Regencia con respecto al gobierno interior del reyno») apuntaba ya que el Poder Ejecutivo era un órgano con atribuciones territoriales en toda España que ejercitaría «valiéndose á este respecto de todos los medios ordinarios y extraordinarios para que está autorizado» ${ }^{33}$.

Centralizador o autonomista, el modelo local establecido en Cádiz, compendiado en los artículos 309 y 310 del texto constitucional, comportaba un cambio revolucionario que rompía la organización administrativa del Antiguo Régimen. Este cambio estaba motivado, en primer lugar, por lo más obvio, es decir, por insertar a los órganos de gobierno del Municipio y de la Provincia en la estructura del Estado, más concretamente en el Poder Ejecutivo si bien con el preciso alcance que explicó el cubano Varela y Morales: «es muy de notar la diferencia que hay entre ejercer el poder ejecutivo y ser agente de él, pues en el primer caso reside una verdadera autoridad o poder gubernativo en la perdona que ejerce las funciones; mas en el segundo, sólo debe decirse que facilita y coadyuva al ejercicio del poder que reside en otro» ${ }^{34}$.

También suponía un cambio notable la opción disgregadora del gran Municipio del Antiguo Régimen que probablemente comportaba un debilitamiento de las oligarquías municipales.

Más problemática resulta la opción uniformista que la Constitución introdujo casi de tapadillo. Según Posada ${ }^{35}$, el uniformismo de la Constitución gaditana derivaba de su artículo $11^{36}$ pero este precepto no tiene suficiente contenido regulador para servir de matriz a un tipo u otro de opción territorial máxime cuando, a fortiori, el modelo centralizador no era bien admitido en

32 Colección de los Decretos y Ordenes..., cit., t. I, págs. 50-58.

33 Antes de la Constitución, hay algunas disposiciones de las Cortes que apuntan una concepción nítida de división de poderes. Por ejemplo, el Decreto XL, de 9 de marzo de 1811 «sobre los memoriales ó solicitudes de que debe darse cuenta en las Córtes» (Colección de los Decretos y Ordenes, cit., t. I, págs. 86-87).

34 Félix VAREla y MORALES: Observaciones sobre la Constitución política de la Monarquía española (1821), Centro de Estudios Políticos y Constitucionales, Madrid, 2008, pág. 74.

35 PosAda: Evolución legislativa del régimen local en España, 1812-1909, cit., págs. 32-33.

36 «Se hará una division mas conveniente del territorio español por una ley constitucional...» 
toda la franja septentrional de España, desde Galicia hasta Cataluña ${ }^{37}$. Como he señalado en otro lugar, el uniformismo surgió como respuesta a la pluralidad municipal del Antiguo Régimen, por coherencia con la incardinación del Ayuntamiento en el Poder Ejecutivo y como respuesta al «federalismo» de algunos Diputados americanos y al fuerismo conservador de algunos Diputados catalanes y valencianos ${ }^{38}$.

Y en ese marco uniformista emerge la nueva figura del Jefe Superior de la Provincia cuyos rasgos prefectorales nadie quiso ocultar ${ }^{39}$. Denostado ${ }^{40}$ por absolutistas y liberales extremos, el Jefe Superior (pronto Político) es un órgano unipersonal de gran carga política y de excelente diseño jurídico que contribuyó, como pocos órganos lo hicieron, a modernizar España y a formar un Estado más eficaz. Es, asimismo, una pieza de cierta relevancia en el diseño del sistema de lo que un siglo después se denominarán órganos constitucionales y denota una buena técnica jurídica pues si bien el Poder Ejecutivo era más fácil de configurar con los antecedentes orgánicos del Antiguo Régimen en Francia y en España, no deja de ser una buena construcción la inserción del Jefe Superior en el continuum orgánico Rey/Ayuntamiento superando el obstáculo dogmático de una relación jerárquica entre órganos de distinta legitimidad democrática (muy indirecta en el caso de los Secretarios de Estado y del Despacho que integran el Poder Ejecutivo y representativa por medio del sufragio indirecto en el caso de los Ayuntamientos). Lo describió muy bien Toreno cuando al cabo de muchas décadas escribió:

«Pareció a muchos que faltaba a esta última rueda de la autoridad pública un agente directo de la potestad ejecutiva, porque los ayuntamientos no son representantes de los pueblos, sino meros administradores de sus intereses ${ }^{41}$.»

Esa buena técnica jurídica no se advierte, en principio, en la configuración de las competencias ex artículo 321 del texto constitucional. Aunque en Francia ya

37 Concepción de CASTRO: La revolución Liberal y los municipios españoles (1812-1868), Alianza Ed., Madrid, 1979, págs. 64-66; y María Cruz Mina APAT: Fueros y revolución liberal en Navarra, Alianza Ed., Madrid, 1981, págs. 62-73.

38 GARCía FERNÁNDEZ: El origen del municipio constitucional: autonomía y centralización en Francia y en España, cit., págs. 285-286.

39 Sobre la configuración inicial del Jefe Político, Manuel Santana Molina: «El rey: gobernadores civiles y diputaciones provinciales desde el siglo XIX», en José Antonio EscUDERO (dir.): El Rey. Historia de la Monarquía, Planeta, Barcelona, 2008, vol. II, págs. 50-53.

40 Véase, por ejemplo, el opúsculo anónimo Examen analítico de la Constitución Politica publicada en Cádiz en 18 de Marzo de 1812, Imp. de Ibarra, Madrid, 1813, págs. 46-56.

41 Conde de Toreno: Historia del levantamiento, guerra y revolución de España (1836), Biblioteca de Autores Españoles, Madrid, 1953, pág. 392. 
se había trabajado dogmáticamente el tema tanto desde la perspectiva del pouvoir municipal (un área de competencias propias y otra de gestión de competencias de otros órganos del Estado) expresado en el Decreto de 14 de diciembre de $1789^{42}$ como desde la perspectiva napoleónica de negación de toda autonomía municipal y, por ende, de toda competencia propia del Municipio, el modelo regulatorio de la Constitución española es aparentemente mucho más tosco, como así creía Posada de Herrera quien veía en la Constitución (no tanto en la Instrucción de 1813) un modelo pensado para que los Ayuntamientos ejercitaran competencias con cierta autonomía ${ }^{43}$. Pero lo cierto, como apuntó García de Enterría, es que se trataba de un modelo organizativo deliberado tomado del modelo napoleónico ${ }^{44}$ : como venía a sugerir Toreno, toda la Administración municipal es Administración periférica.

Y sin embargo, todo ese modelo centralizador, tan sólido, se quiebra al regular las Ordenanzas municipales pues el artículo 321 (que contiene la relación de competencias municipales sin un ámbito privativo) contiene un apartado, el $8^{\circ}$, que rompe el esquema de una Administración municipal-periférica y atribuye a las Cortes la aprobación de las Ordenanzas municipales, si bien con intervención previa de la Diputación Provincial (que preside el Jefe Superior). Durante el Trienio, Ramón Salas interpretó esta autorización parlamentaria en el marco de la preeminencia del Legislativo sobre el Ejecutivo pudiendo aquel limitar los poderes de éste ${ }^{45}$. La escasa vigencia de la Constitución impidió conocer el acierto de esta previsión.

Más original es la figura del Alcalde ${ }^{46}$, lo que no significa que sea un modelo acertado ni acabado. El artículo 275 de la Constitución ${ }^{47}$, que está inserto en el Título V que regula la organización judicial, ofrecía, como dijo Santamaría

42 Javier García FernÁndeZ: «Henrion de Pansey, municipalista doctrinario», Revista de Estudios Políticos, núm. 68, abril-junio 1990, págs. 321-341.

43 José de Posada de Herrera: Lecciones de Administración trasladadas por sus discípulos Juan Antonio de Bascón, Francisco de Paula Madrazo y Juan Pérez Calbo (1843), Instituto Nacional de Administración Pública, Madrid, 1979, t. I, pág. 275.

44 Eduardo GARCía DE ENTERRÍA: «Administración local y Administración periférica del Estado: problemas de articulación», en su obra La Administración española, Alianza Ed., Madrid, 1972, $3^{\mathrm{a}}$ ed. (hay eds. posteriores), págs. 73-75.

45 Ramón Salas: Lecciones de Derecho público constitucional, para las Escuelas de España por... (1821), Centro de Estudios Constitucionales, Madrid, 1982, págs. 284.

46 Se encuentra una síntesis de la figura del Alcalde en Agustín Bermúdez: «Las Cortes de Cádiz ante una nueva organización local. De los corregidores a los alcaldes», en EsCUDERO (dir.): Cortes y Constitución de Cádiz. 200 años, cit., t. III, págs. 257-275.

47 «En todos los pueblos se establecerán alcaldes, y las leyes determinarán la extension de sus facultades, así en lo contencioso como en lo económico». 
Pastor $^{48}$, una configuración preconstitucional al dar a este cargo la doble dimensión administrativa y judicial con lo que se confirma la idea, apuntada por algunos autores, de ciertas continuidad de elementos del Municipio del Antiguo Régimen en la nueva organización municipal ${ }^{49}$. Y aparte esta configuración más propia del Antiguo Régimen, el Capítulo I del Título VI, como hemos visto más arriba, proporciona escasa información sobre la naturaleza jurídica y la posición política de uno de los órganos centrales de la nueva Administración periférica: cargo electivo mudable cada año, inserto en el Poder Ejecutivo, totalmente disociado del Ayuntamiento al que ni siquiera preside de oficio sino por ausencia del jefe Político y con el que sólo se relaciona en una relación inteorgánica de auxilio $^{50}$. Por eso el Alcalde es un órgano mal resuelto en la Constitución que sólo la Instrucción de 1813 logró perfilar aunque hay que señalar en defensa de las Cortes que, como bien señalado Carlos Garriga y Marta Lorente, esta doble naturaleza del Alcalde se debe entender por la escasez de Jueces letrados y su difícil financiación ${ }^{51}$. Aunque, como hemos más arriba, apenas hubo debate parlamentario sobre este órgano lo que se puede explicar por el desconcierto de los Diputados gaditanos que mayoritariamente querían romper con la organización municipal del Antiguo Régimen sin llegar aclarar las características del nuevo órgano. No debemos olvidar que en el lento proceso de asentamiento del Estado constitucional los juristas y los políticos entendían con nitidez la naturaleza y las funciones del Parlamento pero había más confusión doctrinal y práctica sobre el Poder Ejecutivo que muchos concebían todavía con los rasgos del Monar-

48 Juan Alfonso SANTAmaría PASTOR: «Estudio preliminar» conjunto a Vicente VizCaíno PÉREZ: Tratado de la Jurisdiccion ordinaria para la direccion y guia de los Alcaldes de los Pueblos de España, y Francisco de Paula Miguel SÁnCHEZ: Dirección teórico-práctica de alcaldes constitucionales, Instituto de Estudios de Administración Local, Madrid, 1979, págs. 16-18.

49 Alfredo Gallego Anabitarte: «Notas histórico-jurídicas sobre el régimen local español (intento de revisión)», en Actas del II Symposium de Historia de la Administración, Instituto de Estudios Administrativos, Madrid, 1971, págs. 534-539; del mismo Gallego ANABITARTe: «Administración y Jueces: gubernativo y contencioso. Reflexiones sobre el Antiguo Régimen y el Estado Constitucional y los Fundamentos del Derecho administrativo Español» (1971), ahora en su Poder y Derecho. Del Antiguo Régimen al Estado Constitucional en España. Siglos XVIII a XIX. Conceptos, instituciones y estructuras administrativas en el nacimiento del Estado Moderno, Marcial Pons, Madrid, 2009, págs. 130-133; GARCÍA FERNÁNDEZ: El origen del municipio constitucional: autonomía y centralización en Francia y en España, cit., págs. 299-301.

${ }^{50}$ José I. MORILlO-Velarde: El alcalde en la Administración Española, Instituto García Oviedo, Sevilla, 1977, pág. 124.

51 Carlos Garriga y Marta Lorente: «Responsabilidad de los empleados públicos y contenciosos de la Administración (1812-1845). Una propuesta de revisión», en IDEM: Cádiz, 1812. La Constitución jurisdiccional, Centro de Estudios Políticos y Constitucionales, Madrid, 2007, págs. 325-330. 
ca del Antiguo Régimen. En la medida en que la Administración Local era un elemento orgánico inserto en el Poder Ejecutivo, la confusión reinante sobre éste se desparramaba hacia Ayuntamientos y Diputaciones Provinciales.

Por último, el órgano que cierra la estructura del régimen local gaditano es la Diputación Provincial, regulada en el extenso Capítulo II del Título VI. Como hemos visto más arriba, la Diputación Provincial era un órgano híbrido para la tutela municipal, para apoyar al Jefe Superior y para el potencial ejercicio de una acción de fomento. Se trataba de una configuración institucional muy abierta que necesitaba concreción en la normativa de desarrollo.

\section{EL PROFUSO DESARROLLO NORMATIVO DE 1812-1813. I. DISPOSICIONES ANTERIORES A LA INSTRUCCIÓN PARA EL GOBIERNO ECONÓMICO-POLÍTICO DE LAS PROVINCIAS}

Como acabamos de ver, los trazos gruesos de la Constitución precisaban un desarrollo normativo amplio para que los elementos básicos del régimen local adquirieran el suficiente contenido jurídico como para poder ejecutarse al acabar la Guerra. Siempre se pone de ejemplo la Instrucción de 1813 como ejemplo de norma que vino a concretar los contenidos regulatorios abiertos de la Constitución pero antes y después de la Instrucción las Cortes Generales y Extraordinarias produjeron un conjunto de normas de contenido municipal y provincial bastante extenso.

La primera norma de incidencia (si no de contenido) local que dictaron las Cortes después de aprobar la Constitución fue el Decreto CXLV, de 6 de abril de 1812 sobre «Clasificacion de los negocios que pertenecen á las Secretarías del Despacho» ${ }^{52}$. Dejando aparte el significativo hecho de que fuera el Parlamento el que estableciera la planta del Poder Ejecutivo (lo que se repetirá en toda Europa hasta bien entrado el siglo XX), este Decreto de las Cortes atribuía a la Secretaría del Despacho de la Gobernación del Reino para la Península «todo lo perteneciente al gobierno político y económico del reyno, como es la policía municipal de todos los pueblos sin distinción alguna, entendiéndose por ella la salubridad de los abastecimientos y mercados, limpieza y adorno de las poblaciones...» (artículo II). No es que este precepto (muy amplio por abarcar todo aquello que ahora llamamos servicios y obras públicas) agotara las competencias municipales pero debe resaltarse por dos motivos, a saber, porque apunta a algunos de los componentes de las competencias municipales y además porque des-

52 Colección de los Decretos y Ordenes..., cit., t. II, págs. 185-190. 
cribe la conexión orgánica de la política municipal con el Poder Ejecutivo a través de la correspondiente Secretaría del Despacho.

Una vez aclarada la conexión orgánica Gobierno-Ayuntamiento, las Cortes dieron un paso de excepcional importancia al dictar los Decretos CLXIII y CLXIV, ambos de 23 de mayo de 1812, de «Formacion de los ayuntamientos constitucionales ${ }^{53}$ y de "Establecimiento de las Diputaciones provinciales en la Península y Ultramar» ${ }^{54}$. Las aportaciones de estos dos Decretos se compendian de la siguiente manera:

a) Regulación del Ayuntamiento. En aplicación del artículo 310 de la Constitución $^{55}$ y también "para evitar las dudas que pudieran suscitarse en la execucion de lo sancionado por la Constitución, se establezca una regla uniforme para el nombramiento, forma de eleccion y número de individuos», el Decreto CLXIII de formación de los Ayuntamientos estableció las siguientes reglas:

- corresponde al Gobierno, previo informe de la Diputación Provincial, decidir si debe instalarse un Ayuntamiento en los pueblos que no lleguen a mil almas en función de sus particulares características de agricultura, industria o población;

- en cuanto se publique la Constitución en un pueblo, cesarán los Regidores y demás oficios perpetuos y se pasará a elegirlos a pluralidad de votos;

- se establecen reglas para asegurar la proporción entre los habitantes de un pueblo y los cargos municipales que deben establecerse ${ }^{56}$;

- se fija también el número de electores que hay que elegir por pueblo (de nueve a veinticinco) y las fechas de la elección de los electores y de los regidores y la forma de elegir estos últimos;

53 Colección de los Decretos y Ordenes..., cit., t. II, págs. 231-234. Sobre este Decreto, GARCía FERNÁNDEZ: El origen del municipio constitucional: autonomía y centralización en Francia y en España, cit., págs. 274-275; José Manuel CÁRdenAS RodrígueZ De MOYA: «Sistemas de representatividad de las Corporaciones municipales en el constitucionalismo español», Actas del III Symposium de Historia de la Administración, Instituto de Estudios Administrativos, Madrid, 1974, págs. 689-716. Sobre su aplicación, ARTOLA: Los orígenes de la España contemporánea, cit., vol. I, págs. 486-488; y CASTRO: La revolución Liberal y los municipios españoles (1812-1868), cit., págs. 77-80.

${ }^{54}$ Colección de los Decretos y Ordenes..., cit., t. II, págs. 235-237.

55 «Se pondrá ayuntamiento en los pueblos que no lo tengan y en que convenga le haya...».

56 Menos de doscientos vecinos: un Alcalde, dos Regidores y un Procurador Síndico; entre doscientos y quinientos vecinos: un Alcalde, cuatro Regidores y un Procurador Síndico; entre quinientos y mil vecinos: un Alcalde, seis Regidores y un Procurador Síndico; entre mil y cuatro mil vecinos: dos Alcaldes, ocho Regidores y dos Procuradores Síndicos; más de cuatro mil vecinos y capitales de Provincia: dos Alcaldes, doce Regidores y dos Procuradores Síndicos; capitales de Provincia con más de diez mil vecinos: dos Alcaldes, dieciséis Regidores y dos Procuradores Síndicos. 
- la prohibición de que los Ayuntamientos tengan «asesores con nombramiento y dotacion fixa» (artículo XIII).

Este Decreto es de una notable trascendencia porque establece la plena electividad de los oficios municipales aunque no resolvía el tema de la posición de los dos Alcaldes a los que se refería el artículo 314 de la Constitución

En ejecución de este Decreto CLXIII de formación de los ayuntamientos constitucionales, las mismas Cortes dictaron, antes de la Instrucción de 1813, diversas disposiciones que fueron formando un corpus normativo provisional que contribuyó a configurar los rasgos jurídicos de Ayuntamientos. Este corpus normativo era necesario porque en la segunda mitad del año de 1812 se empezaron a elegir Ayuntamientos como lo prueba, por ejemplo, que el 19 de agosto de ese año se eligió el Ayuntamiento de Madrid con dos Alcaldes, dieciséis Regidores, dos Procuradores Síndicos Generales y un Secretario ${ }^{57}$.

También se dictó el Decreto CLXXIX, de 10 de julio de 1812 que contenía «Reglas sobre la formacion de los Ayuntamientos constitucionales ${ }^{58}$ y que venía a ordenar el cese efectivo de todos los regidores perpetuos sin perjuicio de que pudieran ser elegidos en la siguiente elección ${ }^{59}$, se especificaba que para ser elegido Secretario del Ayuntamiento no era necesaria la calidad de escribano. Esta previsión sobre los Secretarios fue completada con otro Decreto de las Cortes, el Decreto CLXXXVII, de 22 de agosto de 1812, «Sobre las escribanías, procuradorías, \& de los lugares que fueron de Señorío» ${ }^{60}$ que ordenaba el pleno cumplimiento del Capítulo I del Título VI de la Constitución en los antiguos lugares de señorío para lo cual transformaba en Secretarios a los titulares de las antiguas Escribanías Públicas de Número, Juzgado y Millones y les encargaba interinamente que sirvieran de Secretarios. Además, ordenaba que el Gobierno proveyera las vacantes producidas y se recomendaba que los nombramientos recayeran en que poseyeran «algun caudal ó bienes para no depender absolutamente de los productos de sus oficios» (artículo IX), lo que denota la noción que se tenía de este oficio municipal.

57 Gazeta de Madrid baxo el Gobierno de la Regencia de las Españas, núm. 6, 27 de agosto de 1812.

58 Colección de los Decretos y Ordenes que han expedido las Cortes Generales y Extraordinarias desde el 24 de Mayo de 1812 hasta 24 de Febrero de 1813. Mandada publicar de orden de las mismas, t. III, 1813, págs. 37-38.

59 Posteriormente, las Cortes aprobaron el Decreto CCXLII, de 24 de marzo de 1813, para que «Los individuos de los antiguos ayuntamientos conserven sus honores \&» (Colección de los Decretos y Ordenes...cit., t. IV, 1813, págs. 18-19) que les autorizaba a conservar los honores, tratamientos y uso de uniforme.

${ }^{60}$ Colección de los Decretos y Ordenes..., cit., t. III, págs. 58-60. 
En esta línea de regular el personal municipal, especialmente a partir de una compleja casuística que llegaba a las Cortes a través de las reclamaciones de los interesados y de los propios Ayuntamientos, se dictó en primer lugar la Orden de Cortes 25 de octubre de 1812 «Sobre si debe haber Contador de propios y arbitrios en los ayuntamientos» ${ }^{61}$ que defería el establecimiento de este oficio a las Ordenanzas municipales y, transitoriamente, ordenaba que allí donde lo hubiese se mantuviese ${ }^{62}$. Poco después las Cortes dictaron la Orden de 7 de noviembre del mismo año «En que se desaprueba la conducta del comisionado en Medinasidonia para jurar la Constitucion \&: y se manda que no haya diferencia entre los dos procuradores síndicos de aquel ayuntamiento ${ }^{63}$, donde se desautorizaba que el Juez interino ejerciera de Alcalde y se recordaba que los artículos 309 y 312 de la Constitución no establecían diferencias entre los dos Procuradores Síndicos. También a partir de una petición de un Ayuntamiento, las Cortes dictaron otra Orden de 19 de noviembre de 1812 que recordaba que «Los gefes políticos no tienen voto en los ayuntamientos; pero sí los alcaldes y procuradores síndicos» ${ }^{64}$, y que es bastante ilustrativa de la doctrina municipal de la Constitución y de las Cortes: «ni la Constitucion concede voto en los ayuntamientos á los gefes políticos, ni pueden dexar de tenerlo, segun ella, los alcaldes y los procuradores síndicos».

Entre los problemas detectados quizá el más grave se encontró en Galicia donde el Jefe Superior, Marqués de Campo Sagrado, no permitió que se constituyeran Ayuntamientos en cincuenta y cinco Municipios, por lo que tanto la Regencia como las Cortes hubieron de ordenar su creación. Las Cortes se vieron obligadas a dictar la Orden de 18 de febrero de 1813 «Sobre la formacion de varios Ayuntamientos en Galicia» ${ }^{65}$, cuyo artículo IV afirmaba taxativamente: «Que ningun gefe político, por ningun prtexto ni motivo, podrá estorbar á los pueblos la formacion de sus ayuntamientos, á menos que le conste que no tienen la poblacion que requiere la Constitucion».

61 Colección de los Decretos y Ordenes..., cit., t. III, págs. 131-132.

62 Reiteraron esta doctrina la Orden de 2 de diciembre de 1812 «Sobre si en los ayuntamientos debe haber el empleo de Contador de propios: se previene al de Cartagena que observe los reglamentos de propios y arbitrios» (Colección de los Decretos y Ordenes..., cit., t. III, pág. 161) y la Orden de 14 de enero de 1813 «Por la qual se declaran las funciones que debe ejercer el Contador de Propios» Colección de los Decretos y Ordenes..., cit., t. III, pág. 182).

63 Colección de los Decretos y Ordenes..., cit., t. III, págs. 145-146.

${ }^{64}$ Colección de los Decretos y Ordenes..., cit., t. III, págs. 151-152. Reiterada por la Orden 13 de junio de 1813 (Colección de los Decretos y Ordenes que han expedido las Cortes Generales y Extraordinarias desde 24 de Febrero de 1813 hasta 14 de Septiembre del mismo año, en que terminaron sus sesiones. Comprehende ademas el decreto expedido por las Córtes extraordinarias en 20 de dicho mes. Mandada publicar de orden de las mismas, t. IV, 1813, pág. 101).

${ }^{65}$ Colección de los Decretos y Ordenes..., cit., t. III, págs. 196-198. 
La casuística electoral fue muy intensa y dio lugar a varias disposiciones de las Cortes. Poco después, el Decreto CXCIII, de 21 de septiembre de 1812, que establecía que "Los eclesiásticos seculares tienen voto en las elecciones de los ayuntamientos, pero no pueden obtener en ellos ningun oficio» ${ }^{66}$, aportaba alguna regulación sobre el derecho de sufragio y las incompatibilidades de los eclesiásticos. La Orden de 18 de diciembre de 1812 que reguló «Cómo se verificarán en Cádiz las elecciones parroquiales para la renovacion de los individuos de su ayuntamiento» ${ }^{67}$ aporta, dentro de su casuística, interesantes aclaraciones sobre el alcance general de las elecciones para elegir electores municipales, aclaraciones que también aportó la Orden de 21 de diciembre de 1812 «Por la qual se manda que en los ayuntamientos instalados quatro meses antes del fin del año ser renueven los dos alcaldes» ${ }^{68}$, que denota la rapidez con que las Cortes querían iniciar los procesos de elección municipal. También se previó el procedimiento para cubrir las vacantes sobrevenidas en los cargos públicos de los Ayuntamientos mediante el Decreto CCXXXII, de 10 de marzo de 1813, que establecía «Cómo se reemplazarán los regidores y demas oficiales de los ayuntamientos» ${ }^{69}$ y que ordenaba: «quando acaeciere la muerte de algun regidor, se nombrará en su lugar otro por los últimos electores, el qual servirá su cargo todo el tiempo que correspondia desempeñarlo al que hubiese fallecido» (artículo I). Para acabar este punto, las Cortes dictaron la Orden de 19 de mayo de 1813 por la que «Se manda observar la ley sobre parentescos en la eleccion de individuos para los Ayuntamientos ${ }^{70}$, que dificultó el acceso a cargos muncipales.

De manera excepcional, las Cortes ordenaron la creación de Ayuntamientos, como se ve en el Decreto CCXLIII, de 24 de marzo de 1813, por el que «Se suprime la Intendencia de las nuevas poblaciones de Andalucía y Sierra-morena: medidas para la formacion de sus ayuntamientos y designacion de su territorio, dehesas, $\&{ }^{71}$. Es excepcional la medida tanto por provenir de las Cortes y no del Poder Ejecutivo como por su indeterminación pues encargaba a los Jefes Políticos proceder a la formación de los Ayuntamientos que correspondan conforme a la Constitución.

b) Regulación del Alcalde. Antes de la Instrucción de 1813 las Cortes también regularon sobre la figura del Alcalde como órgano unipersonal disociado del

${ }^{66}$ Colección de los Decretos y Ordenes..., cit., t. III, págs. 81-82.

67 Colección de los Decretos y Ordenes..., cit., t. III, págs. 168-169.

68 Colección de los Decretos y Ordenes..., cit., t. III, pág. 170.

69 Colección de los Decretos y Ordenes..., cit., t. IV, págs. 7-8.

70 Colección de los Decretos y Ordenes..., cit., t. IV, págs. 69-70.

71 Colección de los Decretos y Ordenes..., cit., t. IV, págs. 19-20. 
Ayuntamiento. El Decreto CXCVIII, de 7 de octubre, de 1812, que ordenaba «Que los Alcaldes constitucionales de los lugares que fueron de señorío ejerzan la jurisdicción civil y criminal» ${ }^{72}$, es una norma atípica, tanto como lo era el precepto constitucional del que trae causa, el ya comentado artículo 275. Si los artículos 242 y 243 de la Constitución no sólo reafirmaban la separación de poderes sino que atribuían el Poder Judicial a los Tribunales y prohibían a los otros Poderes (las Cortes y el Rey) «ejercer en ningun caso las funciones judiciales», ¿cómo se entiende que el artículo 275 siguiera contemplando que los Alcaldes tienen facultades «en lo contencioso»? La duda no la esclareció pero sí la remachó este Decreto CXCVIII, de 7 de octubre, de 1812, que fijó que en los antiguos pueblos de señorío «exerzan los Alcaldes constitucionales que se nombren en ellos la jurisdiccion ordinaria civil y criminal». ¡Menos mal que sólo era en los antiguos pueblos de señorío! El tema no se cerró aquí. El importante Reglamento de las Audiencias y Juzgados de primera instancia, aprobado por Decreto CCI, de 9 de octubre de $1812^{73}$, contenía un largo Capítulo, el III, intitulado «De los Alcaldes constitucionales de los pueblos». En este Capítulo se regulaba en primer lugar la función de conciliador que los artículos 282 a 284 de la Constitución habían atribuido al Alcalde y a continuación se le fijaban competencias en las demandas civiles que no rebasaran los quinientos reales de vellón en la Península y cien pesos fuertes en Ultramar, más «los negocios criminales sobre injurias y faltas livianas» (artículo V del Capítulo III). Igualmente se atribuía a los Alcaldes todas las diligencias judiciales sobre asuntos civiles hasta que llegasen a ser contenciosas en cuyo caso se remitían al Juez del Partido más las contenciosas urgentísimas que no concluían en éste (prevención de inventarios, retractos y similares). Además, en materia penal el Alcalde actuaba de instructor pudiendo prender reos máxime cuando otro artículo, el X, hacía de los Alcaldes el único auxilio del Juez.

Hay que reconocer que esta función judicial de los Alcaldes no era inconstitucional pues desarrollaba con exactitud el artículo 275 pero también es cierto que dogmáticamente venía a quebrar el principio de separación de poderes tan bien trabado en la Constitución. Se puede entender desde un punto de vista pragmático pues las Cortes debieron pensar que era difícil extender una nueva red de Jueces letrados y que más valía conferir las funciones de éstos a unos Alcaldes elegidos democráticamente y a los que no faltaba oficio. Pero la quiebra del principio de separación de poderes era demasiado intensa aunque nunca sa-

72 Colección de los Decretos y Ordenes..., cit., t. III, pág. 92.

73 Colección de los Decretos y Ordenes..., cit., t. III, pp 98-121. 
bremos cómo habría sido la práctica de estos representantes del Poder Ejecutivo dotados de funciones jurisdiccionales.

Menos sorprendente, pero muy interesante para entender la eficacia normativa de la Constitución y la relación entre sus órganos constitucionales, es la Orden de las Cortes de la misma fecha, el 7 de octubre, «En que se manda que los Ayuntamientos auxîlien á los Alcaldes en la persecucion de vagos ya rateros» ${ }^{74}$. En esta disposición las Cortes recordaban la competencia de los Ayuntamientos de auxiliar a los Alcaldes en todo lo que pertenezca a la seguridad de personas y bienes (artículo 321.2 ) y, en consecuencia, excitaban el celo de la Regencia (el Poder Ejecutivo) para que por la Secretaría de Estado de la Gobernación de la Península se tomasen las medidas necesarias para aplicar ese precepto. Es una disposición, como decimos, muy interesante, tanto porque muestra que esa genérica prescripción de auxilio al Alcalde no era una declaración sin contenido, sino también porque muestra las lindes de las atribuciones de cada órgano constitucional: es lo más parecido a lo que hoy llamaríamos una proposición no de ley.

c) Regulación de las Diputaciones provinciales. Simultáneamente al Decreto CLXIII de 23 de mayo de 1812, de «Formacion de los ayuntamientos constitucionales», se dictó el mismo día el Decreto CLXIV, de «Establecimiento de las Diputaciones provinciales en la Península y Ultramar» que vino a aclarar las cuestiones que la Constitución dejó sin esclarecer en lo tocante al número de Provincias. Aunque sin el carácter definitivo contemplado por el artículo 11 de la Constitución, este Decreto creó veintinueve Diputaciones Provinciales en la Península, Baleares y Canarias $^{75}$ y dieciocho en Ultramar ${ }^{76,77}$. Este Decreto tam-

${ }^{74}$ Colección de los Decretos y Ordenes..., cit., t. III, págs. 92-93.

75 En la Península, Aragón, Asturias, Ávila, Burgos, Cataluña, Córdoba, Cuenca, Extremadura, Galicia, Granada, Guadalajara con Molina, Jaén, León, Madrid, Mancha, Madrid, Navarra, cada una de las Provincias Vascongadas, Salamanca, Segovia, Sevilla, Soria, Toledo, Valencia, Valladolid y Zamora. Ulteriormente, el Decreto CCXIII, de 19 de diciembre de 1812 (Colección de los Decretos y Ordenes..., cit., t. III, pág. 169) estableció también la Diputación en la Provincia marítima de Cádiz.

76 Las citadas en el artículo 10 de la Constitución (Nueva España, Guatemala, Provincias internas de Oriente, Provincias internas de Occidente, Cuba, la parte española de Santo Domingo, Puerto Rico, Nueva-Granada, Venezuela, el Perú, Chile, Provincias del Río de la Plata e islas Filipinas) más las de nueva creación de Cuzco, Charcas, San Luis de Potosí, León de Nicaragua y Santiago de Cuba.

77 Pocos meses después, el Decreto CCI, de 9 de octubre de 1812, que estableció el «Reglamento de las Audiencias y Juzgados de primera instancia» (Colección de los Decretos y Ordenes...cit., t. III, págs. 98-121), realizó una similar estructuración judicial y estableció las Audiencias «por aho- 
bién estableció unas reglas provisionales de elección que las propias Cortes completaron con la Orden de 6 de marzo de 1813 por la que «Se anula el nombramiento de la Diputacion provincial de Soria: y se manda que la eleccion de estas Diputaciones debe hacerse por las juntas electorales para las Córtes próximas ordinarias $»^{78}$.

Para estas Diputaciones Provinciales, sin llegar todavía medidas organizativas, el Decreto CLXXXIV, de 11 de agosto de 1812, que establecía «Varias medidas para el mejor gobierno de las provincias que vayan quedando libres» ${ }^{79}$, ordenaba a los Intendentes y Jefes de Provincias nombrar «con calidad de interinos los empleados precisos é indispensables para la administracion y recaudación de rentas y bienes nacionales» (artículo I), que era un primer paso para establecer los órganos provinciales. Las cortes tenían urgencia por establecer las Diputaciones de modo que la Orden de las Cortes 15 de septiembre de 1812, por la que «Se mandan formar las juntas preparatorias para elegir diputados á Cortes y las diputaciones provinciales; y se suprimen las comisiones de partido luego que esten formados los ayuntamientos constitucionales» ${ }^{80}$, ordenó a los Jefes de las Provincias a celebrar elecciones de vocales de la Diputación.

También se dictaron otras medidas de importancia provincial como fue la Orden de Cortes de 13 de octubre de 1812 «En que se declara que el pueblo donde residan las autoridades de cada provincia sea considerado como su capital» ${ }^{81}$.

En lo que se refiere al estatuto de los vocales de las Diputaciones (todavía no se llamaban Diputados), el Decreto CCXLIV, de 24 de marzo de 1813, que estableció «Reglas para que se haga efectiva la responsabilidad de los empleados públicos» ${ }^{82}$, es muy llamativo el siguiente artículo VII del Capítulo II:

«Los regentes del reyno, quando hayan de ser juzgados por delitos cometidos en el uso de su oficio, no podrán ser acusados sino ante las Córtes; y solo ante las mismas, ó ante el Rey ó la Regencia lo serán los secretarios del Despacho y los individuos de las Diputaciones provinciales por los delitos de la propia clase.»

\footnotetext{
ra y hasta que se haga la division del territorio español prevenida en el artículo 11 de la Constitucion» (art. I) si bien había otro precepto constitucional más concreto que se remitía al artículo 11: el 272 sobre la determinación de las Audiencias. Más abajo volveremos sobre este Decreto CCI en relación a los Alcaldes.

${ }^{78}$ Colección de los Decretos y Ordenes..., cit., t. IV, pág. 3.

79 Colección de los Decretos y Ordenes..., cit., t. III, págs. 48-50.

${ }^{80}$ Colección de los Decretos y Ordenes..., cit., t. III, pág. 76.

${ }^{81}$ Colección de los Decretos y Ordenes..., cit., t. III, págs. 126-127.

${ }^{82}$ Colección de los Decretos y Ordenes..., cit., t. IV, págs. 20-29.
} 
Tras este artículo, en el VIII se establecía que todos los individuos antecitados serían juzgados por el Tribunal Supremo si las Cortes declararan que había lugar a formarles causa y quedarían suspendidos en sus funciones, añadiendo a continuación:

«Para que las Córtes hagan la expresada declaración respecto á una Diputación provincial que haya sido acusada ante el Rey, ó suspendida por este, se des dará párte de los motivos con arreglo al propio artículo [el 336 de la Constitución].»

Esta fuero especial llama mucho la atención pues equiparaba a los Diputados provinciales con los Regentes y los Secretarios del Despacho en tanto que el resto de los empleados públicos de superior rango (desde los Consejeros de Estado y los Embajadores hasta los Jefes Políticos y los Intendentes) eran acusados y juzgados ante el Tribunal Supremo sin intervención de las Cortes. Es una extraña peculiaridad de muy difícil explicación pues no es habitual que los empleados de un rango inferior (los Diputados Provinciales) tengan un fuero superior a quien los preside (el Jefe Político).

Como se ve, antes de dictarse la Instrucción para el gobierno económico-político de las Provincias, las Cortes habían configurado los elementos básicos del régimen local. Era una actuación normativa pero también de gestión, lo que llama mucho la atención porque apenas hay actos normativos o de gestión de la Regencia. En el diario oficial sólo hemos encontrado una Circular que la Secretaría de la Gobernación de la Península dirigió el 20 de abril de 1813 a los Jefes Políticos $^{83}$ estableciendo que cualquier instancia que los particulares dirigieran al Gobierno debería tramitarse por conducto del Ayuntamiento o de la Diputación Provincial, según el ámbito territorial del negocio, al tiempo que, repitiendo lo proclamado por la Instrucción de 1812, se animaba a los Jefes Políticos «que son los principales agentes del Gobierno, especialmente encargados de restablecer y consolidar el órden civil prescrito por la constitucion, y de promover cuanto pueda contribuir al fomento y prosperidad de los pueblos de sus respectivas provincias» en esmerarse en proponer al Gobierno todo lo necesario para conseguir tales objetivos. En cualquier caso, es un supuesto muy llamativo de activismo municipal de las Cortes que más abajo glosaremos.

${ }^{83}$ G. R., núm. 59, de 13 de mayo de 1813. Se volvió a publicar en G. R., núm. 69, de 3 de junio de 1813 . 


\section{EL PROFUSO DESARROLLO NORMATIVO DE 1812-1813. II. LA INSTRUCCIÓN PARA EL GOBIERNO ECONÓMICO-POLÍTICO DE LAS PROVINCIAS ${ }^{84}$ Y DISPOSICIONES CONCORDANTES}

El Decreto de las Cortes CCLXIX, de 23 de junio de 1813, aprobó la «Instrucción para el gobierno económico-político de las provincias» ${ }^{85}$. Su estructura es muy significativa porque estaba compuesta de tres Capítulos que regulaban las «obligaciones» de los Ayuntamientos, las «obligaciones» y cargos de las Diputaciones y los Jefes Políticos. Con setenta y ocho artículos, es una completa Ley de régimen local que vino a regular no sólo los dos niveles de organización territorial que emergían de las elecciones sino también la instancia de dirección política que descendía directamente del Poder Ejecutivo aunque cuando, como hemos visto, toda la Administración Local se concebía como Administración periférica.

La Instrucción detallaba las atribuciones municipales sin separarse del artículo 321 de la Constitución, lo que comportaba una relación fundada en la casuística sin que, como también ocurría en la Constitución, se atisbe un criterio doctrinal que ayude a entender porqué esas atribuciones y no otras si bien, como he señalado en otro lugar, estas atribuciones parecen tomadas del Libro VII de la Novísima Recopilación ${ }^{86}$. La consecuencia práctica de esta ausencia de un criterio doctrinal sería un ámbito débil de atribuciones sometido siempre a las decisiones del Jefe Político, de cuya tutela hay atisbos importantes en la Instrucción sobre todo en el artículo XVIII del Capítulo I que confería al Jefe Político el conocimiento de las quejas de los vecinos frente a las providencias del Ayuntamiento o del Alcalde (otros artículos similares son el XIV, XVI, el XVII y el XXIV, todos del Capítulo I). La tutela sobre el Ayuntamiento vuelve a emer-

84 Sobre la Instrucción, GARCíA FeRnÁNDEZ: El origen del municipio constitucional: autonomía y centralización en Francia y en España, cit., págs. 274-280; Ángeles Higiano PéReZ: «Alcaldes constitucionales y jefes políticos: bases del régimen local en la primera etapa del constitucionalismo», Revista de Estudios Políticos, núm. 96, julio-septiembre 1996, págs. 259-271; José CarrióN GuALDA: «La Instrucción de 23 de junio de 1813 para el gobierno económico-político de las provincias y la 'rebelión' de sus Diputaciones», Anuario de Historia del Derecho Español, núm. 67, 1997, págs. 1195-1216; ORduÑa ReBOllo: Municipios y Provincias. Historia de la organización Territorial Española, cit., págs. 306-310; Luis MORELL OCAÑA: «El municipio constitucional y la Instrucción de 1813», en El municipio constitucional. II Seminario de Historia de la Administración, cit., págs. 121145; Orduña Rebollo: Historia del Municipalismo Español, cit., págs. 138-142; y FernándeZ SARASOlA: La Constitución de Cádiz. Origen, contenido y proyección constitucional, cit., págs. 229-231.

${ }^{85}$ Colección de los Decretos y Ordenes..., cit., t. IV, págs. 105-126.

86 GARCÍA FERNÁNDEZ: El origen del municipio constitucional: autonomía y centralización en Francia y en España, cit., pág. 276-278. 
ger en el Capítulo II pues diríase que una parte importante de las atribuciones de las Diputaciones Provinciales están pensadas para tutelar a los Ayuntamientos, aunque es cierto que en este punto la Instrucción repite los preceptos constitucionales. Por último, el Capítulo III regula el estatuto de los Jefes Políticos y lo hace con una cierta precisión, precisión que ayuda a entender como se conformó la primera Administración periférica de la España liberal. Destaca como novedad la creación del Jefe Político subalterno que podría instalarse en los principales puertos de mar o en capitales de Partido de Provincias muy dilatadas o muy pobladas. La idea era interesante aunque el procedimiento para su establecimiento era demasiado largo (audiencia a la Diputación Provincial y al Consejo de Estado, aprobación de las Cortes) (artículo III del Capítulo III).

La Instrucción tenía el gran mérito de ser la primera Ley de Régimen Local de la España constitucional y de describir bien el ámbito de acción municipal a través de las atribuciones de los Ayuntamientos. Pero desde el punto de vista conceptual presentaba ciertas deficiencias porque estaba muy volcaba en remachar la subordinación de Ayuntamientos y Diputaciones al Poder Ejecutivo a través de los Jefes Políticos y no aportaba criterios seguros para entender por qué se fijó ese ámbito competencial municipal (más allá de la copia de la Novísima Recopilación) ni tampoco para construir dogmáticamente la figura del Alcalde o los elementos básicos de la organización municipal que faltan totalmente ${ }^{87}$. Todo ello quizá se deba a que a mediados de 1813 las Cortes tenían como prioridad dar por cerrada la estructura del régimen local con criterios centralizadores porque veían que sólo el impulso del Gobierno y de sus agentes podría modernizar una organización municipal que apenas estaba saliendo del régimen señorial y ello con notables resistencias. En cualquier caso, era un esfuerzo normativo riguroso que debe resaltarse.

Con posterioridad a la Instrucción, las Cortes no aportaron grandes reglas sobre el régimen local. El mismo día en que se aprobó la Instrucción dictaron una Orden de 23 de junio de 1813 «Sobre el nombramiento de Gefes políticos subalternos en algunas provincias» ${ }^{88}$ que derogaba en parte el procedimiento establecido en la misma Instrucción y eximía de informe a la Diputación provincial a la hora de su creación. Posteriormente, un Decreto CCLXXIII, de 3 de julio de 1813 sobre «Supresión de la Contaduría general de Propios» ${ }^{89}$ suprimió este órgano que ya no había perdido sus atribuciones de control. Después se aprobó otro

87 GARCÍA FERNÁNDEZ: El origen del municipio constitucional: autonomía y centralización en Francia y en España, cit., pág. 280.

88 Colección de los Decretos y Ordenes..., cit., t. IV, pág. 126.

89 Colección de los Decretos y Ordenes..., cit., t. IV, pág. 132. 
Decreto, el CCLXXVII, de 19 de julio de 1813, que contenía una «Declaracion del decreto de 6 de Agosto de 1811 sobre la abolicion de los privilegios exclusivos $\& \gg^{90}$, que venía a mostrar la resistencia que encontraba la ejecución del Decreto de abolición de señoríos dos años después de su aprobación si bien, según se deduce del texto, las resistencias se referían a los derechos feudales que a la organización municipal.

Más importancia tuvo el Decreto CCCIV, de 13 de septiembre de 1813, que contenía el «Nuevo plan de contribuciones públicas» ${ }^{91}$, que iba acompañado de la Instrucción de la misma fecha «Para las Diputaciones provinciales, que acompaña al decreto de las Córtes generales y extraordinarias de 13 de Septiembre de 1813 , dirigida a uniformar y facilitar la execucion del mismo decreto, y establecimiento de una contribución directa sobre la riqueza territorial, industrial y comercial, en lugar de las Rentas provinciales y estancadas que quedan extinguidas ${ }^{92}$. La importancia de ambas disposiciones, además de la estrictamente contributiva y de suprimir las aduanas interiores, estribaba en modernizar la Hacienda municipal y en confirmar la función de distribución de los cupos municipales que correspondía a las Diputaciones Provinciales además de confirmar la competencia municipal en la recaudación.

Esta fue la última disposición de las Cortes con relevancia municipal. Siete meses después, el 4 de mayo de 1814, el Rey restaurado dictaba en Valencia el Decreto que extinguía los Jefes Políticos y unía el mando político en los Capitanes y Comandantes Generales de las Provincias ${ }^{93}$. El Municipio constitucional desaparecía durante seis años.

\section{CONCLUSIÓN}

A diferencia de Constituciones posteriores, la de 1812 aportó una regulación larga y detallada del régimen local. Con lenguaje preciso y, sobre todo, jurídicamente riguroso, la Constitución transformó totalmente la base social y política de España, que descansaba lógicamente en unas entidades locales que apenas estaban saliendo del feudalismo. No contentas con la regulación constitucional, las Cortes Generales y Extraordinarias mostraron gran activismo local antes y después de

90 Colección de los Decretos y Ordenes..., cit., t. IV, págs. 139-140.

91 Sobre este Decreto, José SARRIÓN GUALDA: «La reforma fiscal de las Cortes de Cádiz y la distribución provincial de la carga tributaria», en EsCudero (dir.): Cortes y Constitución de Cádiz. 200 años, cit., t. III, págs. 314-324.

92 Decreto e Instrucción en Colección de los Decretos y Ordenes..., cit., t. IV, págs. 229-241.

93 G. M., núm. 75, de 21 de mayo de 1814. 
elaborar la Constitución y ese activismo desembocó en la Instrucción para el gobierno económico-político de las provincias de 23 de junio de 1813 que se puede considerar la primera Ley de Régimen Local de la España contemporánea. Las Cortes sabían lo que hacían pues si no transformaban la estructura del gobierno local, de nada serviría crear un Estado fundado en la división de poderes y en el reconocimiento de los derechos y libertades. Fue una obra, la de las Cortes, extensa e intensa, que, con sus deficiencias, contribuyó a asentar el Estado constitucional. El municipio constitucional fue el primer escalón de la democratización del Estado.

Title:

THE MUNICIPALITY AND THE PROVINCE IN THE 1812 CONSTITUTION

\section{Summary:}

1. INTRODUCTION. 2. THE NORMATIVE ANTECEDENTS AND THE CONSTITUTIONAL DEBATE. 3. CONSTITUTIONAL REGULATION. 4. CHARACTERISTICS OF THE LOCAL REGIME IN THE CONSTITUTION. 5. THE PROFUSE NORMATIVE DEVELOPMENT OF 1812-1813. I. DISPOSITIONS PREVIOUS TO THE INSTRUCTION FOR THE ECONOMIC-POLITICAL GOVERNMENT OF THE PROVINCES. 6. THE PROFUSE NORMATIVE DEVELOPMENT OF 1812-1813. II. THE INSTRUCTION FOR THE ECONOMIC-POLITICAL GOVERNMENT OF THE PROVINCES CONCORDANT DISPOSITIONS. 7. CONCLUSION.

\section{Resumen:}

El modelo local establecido por la Constitución de Cádiz de 1812 comportó un cambio revolucionario que resquebrajó la organización administrativa del Antiguo Régimen, insertando los órganos de gobierno del municipio y de la provincia en la estructura del Estado.

La Constitución gaditana alteró la base social y política de España que gravitaba sobre unas entidades locales que estaban liberándose del feudalismo, y reguló profusamente el régimen local. Después de su aprobación, las Cortes Generales y Extraordinarias mostraron gran activismo local desembocado en la Instrucción para el gobierno económico-político de las provincias de 23 de junio de 1813, que se puede considerar la primera Ley de Régimen Local de la España contemporánea. 


\begin{abstract}
:
The local model established by the Constitution of Cadiz of 1812 tolerated a revolutionary change that cracked the administrative organization of the Old Regime, inserting the control systems of the municipality and the province in the structure of the State.

The Cadiz Constitution altered the social and political base of Spain that weighed on local organizations that were being freed of the feudalism, and regulated the local regime profusely. After their approval, General and Extraordinary Cortes showed great local activism ended at the Instruction for the economic-political government of the provinces of 23 of June of 1813, that can be considered the first Law of Local Regime of contemporary Spain.
\end{abstract}

Palabras clave:

Régimen local, Municipio, Ayuntamiento, provincia, Diputación provincial.

Key words:

Local regime, Municipality, Council, province, provincial Delegation. 